\title{
Green Marketing Perception: A Study on Konya Automotıve Supplier Industry
}

\author{
Phd. Student, V. Özlem Akgün \\ Selcuk University Faculty of Economics and Administrative Sciences \\ ozlemakgun@selcuk.edu.tr
}

\section{Associate Professor Dr. Muammer Zerenler}

Selçuk University Faculty of Economics and Administrative Sciences

zerenler@selcuk.edu.tr

\section{Research Assistant Esen Şahin}

Selcuk University Faculty of Economics and Administrative Sciences esenboztas97@hotmail.com

Doi:10.5901/mjss.2013.v4n10p758

\begin{abstract}
Environment is, of vital importance to all living things. Destruction of environment means destruction of the life itself. Previosly the sources like weather, water, soil were assumed to be unlimited but either by individuals or as a result of incorrect use of businesses, they have begun to be contaminated and eventually there has been a reduction of sources as a natural result. One of the biggest and most important problem of the present century we are living in is global warming that is highly related with environment. The surveys having been kept since 1800 's indicate that, there has been a strong decrease of global warming that negatively affects the life of living things. Scietists declare the high decrease of temperature in the past 50 years has shown visible negative effects on human life. The perception of environment with this global warming issue has forced modern consumer to behave in a more explotary, conscious and selective way. In return, businesses with the required sensitivity of being a socio_economic entitiy have started shown awareness to environment and have modified their service and production and have changed their strategy from traditional to green marketing. In this article, an overview of green marketing concept is studied and green marketing is compared with traditional marketing. In the last section, a survey to measure the perception of green marketing among the businesses in Konya Automotive supply industry is presented with the results and outcomes of this survey.
\end{abstract}

Keywords: Green marketing, Traditional marketing, Environmental problems

\section{Introduction}

The fact that the competitive conditions have changed with the effect of globalization is accepted by everybody. If the needs and desires of customers are met with the desired quality and at the proper time and place, they express a meaning. While the environmental problems are reaching a critical level, the businesses moving towards green marketing and being conscious about environment will have the chance to survive. To ensure sustainability, to compete even to compete greater, one of the most important tasks of the businesses is to implement environmental awareness and the perception of green marketing in all units of the entitiy. The vast majority of people think environmentally friendly products as a form of advertising strategy decorated with green marketing terms. Terms such as phosphate free, ozone layer, environmentally friendly are usually the first ones that come to mind of consumers (Murthy, 2010). Rather than producing products that put emphasis on human health just on the packages, the environmentally friendly and sensitive emphasis should be done in all stages starting with the born of production idea to after sales support service. In this context, each employee in each level including manager and a lower level worker should act in green marketing concious. The enviroment conscious and effort to protect it started centuries ago when human started to know about nature. However, with the increase of environmental problems and the negative effects have become more visible, the environmental issues also have become more questionable. Since the second half of the 20 'th century, some quite extensive surveys at international level supported by strong evidences were carried out. Especially since the 1990 's, 
businesses, goverments, national and international environmental organizations have been doing important work in this direction and have achieved a great success in drawing communities' attention. On the basis of many common environmental problems of the world, there lies an imbalance between economy and environment. While human beings have been dominating the nature with the help of rapidly developing science, technology and industry and upgrading their life standart economically, they also have been damaging the environment (Evirgen; 1997, 34). Businesses have great responsibility in solving environmental problems. They need to develop new projects on possible scenarios before they emerge. Since environment is vital importance to communities, businesses are forced to organise their activities in this way (YIImaz, 2003: 28). Grove and his friends suggest that businesses can initiate in green marketing by using one or more of the 3 activities: Reusing, Recycling and Reducing. These 3R formulated broad activities in environmental management aim to control the naturel source waste of the organisation. Re-use (re-fillable containers), recyclable materials (reforming of used products), and reducing the use of resources (energy conservation in the production process), make significant contrubitions for businesses to have a positition in public's mind as a green friendly organisation (Keleş, 2007: 23). Business management called as environmentally conscious management, environmentalfriendly management or green management is a perception which respects the environment in all activities of organizations, minimizes damage to the environment, changes production processes, trains employees with environmental awareness, uses technologies that do not harm the environment, and develops projects for the good of ecological environment (Karabulut, 2004: 55). Only the businesses which carry on the activities within the framework of this approach will be accepted by consumers and will be long lasting.

\section{Green Marketing Concept}

Green marketing is truly the definition of a structure that is very difficult and relatively. And the definition must be compatible with the changes coming in time. The meaning of today's green cases may lose their meaning years later. For example, when first invented, chlorine-flora-carbons of was considered to be excellent, but unfortunately, in the light of today's technological world, it is accepted as a harmful substance (Uydacı, 2011: 127). For this reason, enterprises should follow all the facts about green and management decisions should be taken in this direction.

The concept of green marketing is associated with different names like ecological marketing, environmental marketing, sustainable marketing, , first emerged at seminar on ecological marketing organized by, the American Marketing Association (AMA) in 1975. This seminar is based on the recognition of ecological marketing, "marketing activities, environmental pollution, energy consumption and energy-free positive or negative effects on resource consumption studies." This first definition contains three key parts (Uydacı, 2011: 127): It is the subset of all marketing. It analyses both positive and negative studies. It covers the case of very large-scale environment. Over time there were very different definitions about green marketing. These definitions show that, the concept of green marketing has a relative structure, and definitions differ over time with environmental issues that evolve. According to Stanton (1993) green marketing states, how natural resources are used in marketing activities in the processes starting with accomplishment of sales objectives of organization to satisfaction of individuals, industry and consumers. For Ottman; (1993) green marketing is a business project which has accepted to be responsible for detecting and satisfiying the needs of consumers without ignoring the profitability in the long term. Polonsky (1994) defines green marketing as doing all kinds of activities intended to satisfy human wants and needs with minimum detriment to the natural environment. Peattie, in an article he wrote in 2001,defines green marketing as the marketing activities that aim to minimize the negative social and environmental impacts caused by production systems and to produce products and services that are less harmful. He tried to explain these marketing activities in 3 phases that create quite different effects on marketing discipline (Quoted from Peattie by Kacur, 2008).

- Eco marketing: In a narrow scope mainly focuses on reducing dependence on certain products which are considered to be harmful.

- Environmental marketing: With a more comprehensive initiative, it tries to reduce environmental damage using the green consumer demands and opportunities of copmpetetive advantages.

- Sustainable marketing: With a much more radical approach it tries to meet all the environmental costs of production and consumption to create a sustainable economy.

According to Karna (2003), green marketing is a hollistic management process that is responsible for predicting, identifiying and satisfiying the needs of consumers and society with a profitable and sustainable way. Marangoz (2003), defines the purpose of green marketing as to transfer its consumers, educational information, inform them how to use limited resources in accordance with the principles of sustainable development and within the entire organization to 
ensure that consumers' desires and needs are met. For Torlak (2009), green marketing is the effective and efficient use of social resources, It also stops the pollution, keeps the health and safety of the consumers without misleading and deceptive activities. According to the Türk and the Gök (2010) green marketing is an approach that aims to understand environmental issues in marketing trials, to be sensitive to these issues, to contribute to balance the uneven distribution of resources and avoid socially damaging behaviours in marketing decisions and mattersSingh (2010) defines green marketing as the sales process of environment-friendly products and services. According to Uydacı (2011) green marketing is a group of activities that evoke changes which are willing to satisfy the needs of the society by causing a minimum damage to the environment.

\section{Comparison of Green Marketing with Traditional Marketing}

There are significant differences between green marketing and traditional marketing. Green marketing in accordance with the principle of sustainability has emerged as a stance against the traditional marketing concept that directs consumers to consume without questioning and go beyond satisfiying needs (Turgul, 2009: 56). Traditional marketing includes providing products at, affordable rates for consumers. Green marketing on the other hand is more complex and requires new marketing strategies that need active struggle to capture attention of consumers on how the environmentally friendly products are created and how they are defined (Uydacı, 2011: 130).Traditional marketing is, meeting consumers' needs with affordable products and presenting these products with communication channels emphasizing that consumer is worth. Green marketing studies, how natural resources are used in marketing activities in the processes starting with accomplishment of sales objectives of organization to satisfaction of individuals, industry and consumers (Ar, 2011: 74).Green marketing products are in a transparent and suspicious search of reality to create a more informed and conscious consumer about the brand. However in traditional marketing, most of the brand, is marketed with 'envy', and desire to be special. Creating a brand used by famous and rich and projecting this feature to brand communication in order to create an environment of envy, longing and acceptance is the main objective (Turgul, 2009: 64). Respect to commercial concerns in a business environment, does not mean that green marketing activities were created and implemented properly. Respect for the environment, should include all activities within the organization (Uydacl, 2011: 130). On Table 1. traditional marketing and green marketing are compared in terms of parties of trade, objectives, organizational responsibility, achieving marketing decision, ecological demand and green pressure groups.

Table 1. Traditional Marketing And Green Marketing Comparison

\begin{tabular}{|l|l|l|}
\hline \multicolumn{1}{|c|}{ Traditional Marketing } & & \multicolumn{1}{c|}{ Green Marketing } \\
\hline Business and customer & Parties of trade & Business, customer, environment \\
\hline $\begin{array}{l}\text {-Customer satisfaction } \\
\text {-Meeting the business objectives }\end{array}$ & Objectives & $\begin{array}{l}\text {-Customer satisfaction } \\
\text { - Meeting the business objectives } \\
\text {-Reduction of environmental damage }\end{array}$ \\
\hline Economical responsibility & Organizational responsibility & Social responsibility \\
\hline From production to production usage & Achieving marketing decision & Üretim İçin Malzeme Alımından Tüketim Sonrasına \\
\hline Legal obligations & Ecological demands & Beyond the law : Environmental culture \\
\hline Confrontation or passive behaviour & Green pressure groups & Public relations and cooperation \\
\hline
\end{tabular}

Source: Antonio Chamorro ve Tomas M.Banegil, (2006). Gren Marketing Philosopy: A Study of Spanish Firms With Ecolabels, Corporate Social Responsibility and Environmental Management, Volume: 13, 13

\section{Perception of Green Marketing: A Research on Konya Automotive Supply Industry}

\subsection{Purpose of the Study}

The main purpose of this research, is to state green marketing perception of businesses. To achieve this goal, a survey was conducted in the province of Konya, with 57 businesses operating in the automotive supply industry. The majority of survey questions were taken from the Ph. D. Thesis of Kacur in 2008 (Kacur, 2008). 


\subsection{Hypothesis of the Study}

In order to make the subject to be more clearly understood, some hypotheses were involved in the research. It is possible to state the developed hypotheses about the research related to the purposes of the research in the following way;

- H1: There is a significant difference between business managers with different levels of education in terms of green marketing practices and its lower dimensions.

- $\quad \mathrm{H} 2$ : There is a significant difference between business managers with different levels of education in terms of understanding the reasons of green marketing applications and their opinions differ about the sub dimensions of green marketing

- H3: There is a meaningful relationship between business activity duration and green marketing imlementations and its sub dimensions.

- $\mathrm{H} 4$ : There is a meaningful relationship between business activity duration and reasons of green marketing imlementations and its sub-dimensions.

- H5: There is a significant difference among the participants who work in businesses with different staff number in terms of the views of green marketing implementations and its sub dimensions.

\subsection{Determination of the Research Sample}

Konya Chamber of Industry (KSO) was taken to this research due to the reasons of its up to date database, including all the businesses due to the legal obligation of being a member and easy access to profile information of member organizations. After the Database of KSO had been analyzed, the companies operating in the automotive supply industry were examined, "inactive",businesses or the ones which "do not meet the criteria" or which are not suitable in scale were eliminated so the universe of the study was determined. In this context, the research sample includes, business owners, partners of the companies, managers, and department managers of 57 businesses operating in auto supply industry in the province of Konya. "Direct contact" has been tried to be made during the research. In addition, to 18 companies which can not be reached by direct negotiation, questionnaires were sent out via e-mail. As of January 20, 2012, 57 questionnaires suitable for evaluation were obtained.

\subsection{Data Analysis}

The data set obtained from the survey was analyzed with SPSS 19.0 (Statistical PackageforSocialSciences) package program. Within the scope of analysis, frequency tables, reliability and validity analysis, the Kaiser-Meyer-Olkin measure of sampling adequacy, Bartlett test, factor analysis, Pearson Correlation analysis, one-way analysis of variance and Tukey's test were utilized.

\subsection{Results}

\subsubsection{Evaluation of the appropriateness of the data set for factor analysis}

Kaiser - Meyer -Olkin measure of sampling adequacy and Barlett test were applied to data set to determine the appropriateness of factor analysis before the factor analysis stage. With Bartlett test, the null hypothesis was tested and that means "correlation matrix is identity matrix. The rejection of the hypothesis means that there are high correlations between the variables, in other words, the data set is suitable for factor analysis. KMO measure of sampling adequacy is a test that compares the size of observed correlation coefficients with partial correlation coefficients. KMO rate must be greater than 0.50 . The higher the ratio there is, the better the data is for factor analysis. KMO values and reviews are as follows:

Table 2. KMO Values And Reviews

\begin{tabular}{cc}
\hline KMO & Review (comment) \\
\hline 0,90 & Excellent \\
\hline 0,80 & Very good \\
\hline
\end{tabular}




\begin{tabular}{cc}
\hline 0,70 & Good \\
\hline 0,60 & Average \\
\hline 0,50 & Weak \\
\hline$<0,50$ & Unacceptable \\
\hline
\end{tabular}

When Bartlett and KMO test results were applied to the data set and the factor analysis, the following results were obtained:

\subsubsection{Factor Analysis (Green marketing perception scale)}

Factor analysis was conducted to test whether the 18 judical components which were created to understand participants' views on the implementation of green marketing were gathered under specific factors. Before starting the factor analysis of the data, the reliability analysis was performed to determine whether it has a consistency of its own. Reliability coefficient (Cronbach's alpha) was determined as 0.845 . According to this criterion, the scale is reliable.

Table 3. Factor Analysis Table (Green marketing perception scale)

\begin{tabular}{|c|c|c|c|}
\hline Factors and variables & Factor loadings & Variance (\%) & Eigenvalue \\
\hline Factor 1(recycling applications and infrastructure) & & 18,541 & 5,326 \\
\hline $\begin{array}{l}\text { Environmental impact isn't taken into consideration during production } \\
\text { in our organization. }\end{array}$ & 0.862 & & \\
\hline $\begin{array}{l}\text { Packaging materials used in our organization can be recycled and } \\
\text { reused. }\end{array}$ & 0.761 & & \\
\hline Waste management unit isn't available in our business. & 0.681 & & \\
\hline $\begin{array}{l}\text { Green product (environmentally sensitive products) are not preferred } \\
\text { much in our business as it is a cost effective activity. }\end{array}$ & 0.600 & & \\
\hline $\begin{array}{l}\text { We always emphasize that our products are green (environmentally } \\
\text { friendly). }\end{array}$ & 0.538 & & \\
\hline We do not have an adequate infrastructure for green marketing. & 0.494 & & \\
\hline $\begin{array}{l}\text { Marketing strategies of our products are greatly influenced by the } \\
\text { issues related to environmental protection. }\end{array}$ & 0.482 & & \\
\hline Our products are designed to be reused. & 0.387 & & \\
\hline Factor 2 (Qualification \& Sensibility) & & 15,636 & 2,109 \\
\hline $\begin{array}{l}\text { Our organization has the certificates of environmental management } \\
\text { standards. }\end{array}$ & 0.787 & & \\
\hline $\begin{array}{l}\text { We organize our distrubition channels with the least harm to } \\
\text { environment. }\end{array}$ & 0.715 & & \\
\hline $\begin{array}{l}\text { We participate in sponsorship activities related to environmental } \\
\text { issues because it is important for our image.. }\end{array}$ & 0.691 & & \\
\hline Factor 3 (Responsibility ) & & 11,877 & 1.963 \\
\hline $\begin{array}{l}\text { The objective of green (environmentally friendly) communication } \\
\text { should be to create environmentally conscious consumers and } \\
\text { society. }\end{array}$ & 0.763 & & \\
\hline $\begin{array}{l}\text { Our green marketing activities are not affected by the competitior } \\
\text { businesses. }\end{array}$ & 0.681 & & \\
\hline Our organisation has a responsibility to protect the environment. & 0.603 & & \\
\hline Factor 4 (Green Advertising applications) & & 11,644 & 1.450 \\
\hline $\begin{array}{l}\text { The aim of the green ads should be to provide clear, realistic } \\
\text { information to consumers about the environmental effects of the } \\
\text { product. }\end{array}$ & 0.858 & & \\
\hline $\begin{array}{l}\text { Businesses that can implement green marketing strategies } \\
\text { successfully will survive. }\end{array}$ & 0.623 & & \\
\hline $\begin{array}{l}\text { Green ( environmentally friendly ) ads should to provide clear, } \\
\text { realistic information to consumers about the environmental effects of } \\
\text { the product. }\end{array}$ & 0.592 & & \\
\hline Factor 5 (Financial factors ) & & 8,827 & 1.026 \\
\hline
\end{tabular}


Green marketing is a cost factor for businesses.

0.739

KMO, 0,663, Barlett's test:458,432; $p<0.000$

The result of factor analysis shows that the scale was collected under 5 factors. All of the factors explain the $66,53 \%$ of the total variance.

\subsubsection{Factor Analysis ( Scale of Green marketing applications/implementations causes )}

Factor analysis was conducted to test whether the 10 judical components which were created to understand participants' reasons for choosing green marketing implementations were gathered under specific factors. Before starting the factor analysis of the data, the reliability analysis was performed to determine whether it has a consistency of its own. Reliability coefficient (Cronbach's alpha) was determined as 0778. According to this criterion, the scale is reliable.

Table 4. Factor Analysis Table ( Scale of Green marketing applications/implementations causes )

\begin{tabular}{|c|c|c|c|}
\hline Factors and Variables & Factor Loadings & Variance (\%) & Eigenvalue \\
\hline Factor 1 (Pressure and external origin) & & 24,504 & 3,588 \\
\hline Suppliers have become environmentally conscious. & 0.837 & & \\
\hline Green consumers' pressure & 0.829 & & \\
\hline Increasing competitive pressure & 0.681 & & \\
\hline Increasing pressure from environmental groups & 0.300 & & \\
\hline Impact of environment on costs & 0.570 & & \\
\hline Factor 2 (Standards and environmental origin) & & 21,353 & 1,878 \\
\hline Legal obligations & 0.785 & & \\
\hline Increasing environmental standards & 0.724 & & \\
\hline Incorrect use of natural resources & 0.696 & & \\
\hline $\begin{array}{l}\text { Increasing concern of safety and health depending on the } \\
\text { environment }\end{array}$ & 0.543 & & \\
\hline Factor 3 (responsibility - sensitivity origin ) & & 15,992 & 1.337 \\
\hline Social responsibility of organizations & 0.784 & & \\
\hline Management has become environmentally aware & 0.557 & & \\
\hline
\end{tabular}

KMO, 0,694, Barlett's test: 196,330; $p<0.000$

The result of factor analysis shows that the scale was collected under 5 factors. All of the factors explain the $61,84 \%$ of the total variance.

\subsubsection{Information on Demographic Characteristics of Participants and Business Operating Time}

Table 5. Demographic Characteristics

\begin{tabular}{|l|c|c|}
\hline Distribution of Titles & F & $\%$ \\
\hline Deputy Manager & 6 & 10.5 \\
\hline Marketing Manager & 15 & 26.3 \\
\hline Company Partner & 11 & 19.3 \\
\hline Company Owner & 2 & 3.5 \\
\hline General Manager & 1 & 1.8 \\
\hline Quality Control Manager & 2 & 3.5 \\
\hline Production Manager & 3 & 5.3 \\
\hline Finance Manager & 6 & 10.5 \\
\hline Director & 11 & 19.3 \\
\hline Distribution of Educational Attainment & F & $\%$ \\
\hline \multicolumn{2}{|l|}{} \\
\hline Primary School & 1 & 1.8 \\
\hline High School & 15 & 26.03 \\
\hline University & 31 & 54.4 \\
\hline
\end{tabular}




\begin{tabular}{|l|c|c|}
\hline Postgraduate & 10 & 17.5 \\
\hline Number of Personnel & F & $\%$ \\
\hline $1-49$ & 43 & 75.4 \\
\hline $50-199$ & 11 & 19.3 \\
\hline $200 \mathrm{ve}+$ & 3 & 5.3 \\
\hline
\end{tabular}

The majority of participants involved in the study, are marketing managers with percent of $26.3 \%$. Managers and company owners are with a number of $19.3 \%$ in the second place in this category. The majority of the participants (54.4\%.)have university-level education. When the distribution of the number of staff working in the firm is analyzed it is seen that; 1-49 employees work in75.4\% of the businesses while 50-199 work in\%19,3 and more than 200 people are employed in $5.3 \%$ of the businesses.

Table 6. Operating Time Distribution

\begin{tabular}{ccccc}
\hline $\mathbf{N}$ & Minimum & Maximum & Average & SS \\
\hline 57 & 5.00 & 42.00 & 15.3860 & 8.82317 \\
\hline
\end{tabular}

Finally, when the businesses are examined in terms of the duration of activity, it is seen they have been active in an average of 15 years. The minimum duration of activity is 5 and the maximum is 42 years.

\subsubsection{Perception Of Green Marketing}

Table 7. Descriptive Statistics On The Scale Of The Perception Of Green Marketing

\begin{tabular}{|c|c|c|c|c|}
\hline Judgements & Min. & Maksi. & Ort. & SS \\
\hline Our organisation has a responsibility to protect the environment. & 1.00 & 5.00 & 4.0351 & 0.92514 \\
\hline $\begin{array}{l}\text { Environmental impact isn 't taken into consideration during production in } \\
\text { our organization. }\end{array}$ & 1.00 & 5.00 & 2.2105 & 1.01307 \\
\hline $\begin{array}{l}\text { We always emphasize that our products are green (environmentally } \\
\text { friendly). }\end{array}$ & 2.00 & 5.00 & 3.2456 & 0.82982 \\
\hline $\begin{array}{l}\text { Marketing strategies of our products are greatly influenced by the issues } \\
\text { related to environmental protection. }\end{array}$ & 2.00 & 5.00 & 3.4912 & 0.94723 \\
\hline $\begin{array}{l}\text { Green product (environmentally sensitive products) are not preferred } \\
\text { much in our business as it is a cost effective activity. }\end{array}$ & 1.00 & 5.00 & 2.5789 & 1.17940 \\
\hline Waste management unit isn't available in our business. & 1.00 & 5.00 & 2.9825 & 1.27463 \\
\hline $\begin{array}{l}\text { The objective of green (environmentally friendly) communication should } \\
\text { be to create environmentally conscious consumers and society. }\end{array}$ & 3.00 & 5.00 & 4.2807 & 0.67492 \\
\hline $\begin{array}{l}\text { We participate in sponsorship activities related to environmental issues } \\
\text { because it is important for our image. }\end{array}$ & 1.00 & 5.00 & 2.8596 & 1.23112 \\
\hline $\begin{array}{l}\text { The aim of the green ads should be to provide clear, realistic information } \\
\text { to consumers about the environmental effects of the product. }\end{array}$ & 3.00 & 5.00 & 4.3684 & 0.55522 \\
\hline $\begin{array}{l}\text { Packaging materials used in our organization can be recycled and } \\
\text { reused. }\end{array}$ & 2.00 & 5.00 & 3.7368 & 0.97333 \\
\hline $\begin{array}{l}\text { Businesses that can implement green marketing strategies successfully } \\
\text { will survive. }\end{array}$ & 2.00 & 5.00 & 3.9474 & 0.89485 \\
\hline Green marketing is a cost factor for businesses. & 1.00 & 5.00 & 3.6491 & 0.89625 \\
\hline $\begin{array}{l}\text { Our green marketing activities are not affected by the competitior } \\
\text { businesses. }\end{array}$ & 1.00 & 5.00 & 3.3333 & 0.95119 \\
\hline We do not have an adequate infrastructure for green marketing. & 1.00 & 5.00 & 3.0351 & 1.10138 \\
\hline Our products are designed to be reused. & 2.00 & 5.00 & 3.4211 & 0.75468 \\
\hline $\begin{array}{l}\text { We organize our distrubition channels with the least harm to } \\
\text { environment. }\end{array}$ & 1.00 & 5.00 & 3.5965 & 0.88357 \\
\hline $\begin{array}{l}\text { Green ( environmentally friendly ) ads should to provide clear, realistic } \\
\text { information to consumers about the environmental effects of the product. }\end{array}$ & 2.00 & 5.00 & 4.0877 & 0.78560 \\
\hline
\end{tabular}




\begin{tabular}{lllll}
\hline $\begin{array}{l}\text { Our organization has the certificates of environmental management } \\
\text { standards. (ISO 14000, BS 7750, EMAS etc.) }\end{array}$ & 1.00 & 5.00 & 3.2807 & 0.88144 \\
\hline
\end{tabular}

When the descriptive statistics table is examined for the analysis of scale, it is clearly seen that the judgement' the aim of the green ads should be to provide clear, realistic information to consumers about the environmental effects of the product' becomes the most accepted one with an average of 4.36 among the judgements of participants. On the other hand, the judgement "Environmental impact isn "t taken into consideration during production in our organization" becomes the least accepted one with an average of 2.21 .

\subsubsection{Implementation Of Green Marketing Reasons}

Table 8. Descriptive Statistics On The Scale Of Implementation Of Green Marketing Reasons

\begin{tabular}{lcccc}
\hline Judgements & Min. & Maksi. & Ort. & SS \\
\hline Incorrect use of natural resources & 2.00 & 5.00 & 3.9298 & 0.86313 \\
\hline Legal obligations & 2.00 & 5.00 & 4.0175 & 0.66792 \\
\hline Increasing pressure from environmental groups & 1.00 & 5.00 & 3.1754 & 1.00219 \\
\hline Social responsibility of organizations & 2.00 & 5.00 & 4.1228 & 0.82527 \\
\hline Increasing competitive pressure & 2.00 & 5.00 & 3.7544 & 0.71416 \\
\hline Impact of environment on costs & 2.00 & 5.00 & 3.6491 & 0.81265 \\
\hline Increasing environmental standards & 3.00 & 5.00 & 3.7895 & 0.64744 \\
\hline Green consumers' pressure & 1.00 & 5.00 & 3.3158 & 1.07168 \\
\hline Suppliers have become environmentally conscious. & 2.00 & 5.00 & 3.1228 & 0.92717 \\
\hline $\begin{array}{l}\text { Increasing concern of safety and health depending on the } \\
\text { environment }\end{array}$ & \multirow{2}{*}{3.00} & 5.00 & \multirow{2}{*}{4.1228} & 0.73364 \\
\hline Management has become environmentally aware & 2.00 & 5.00 & 3.5263 & 0.82603 \\
\hline
\end{tabular}

When the descriptive statistics table is examined for the analysis of scale, it is clearly seen that the judgements' Social responsibility of organizations and" Increasing concern of safety and health depending on the environment" become the most accepted one with an average of 4.12 among the judgements of participants. On the other hand, the judgement "Management has become environmentally aware" becomes the least accepted one with an average of 3.12 .

\subsubsection{Scales and Sub Dimensions}

Table 9. Scales and Mean Scores of Sub Dimensions

\begin{tabular}{lcc}
\hline & Avg. & SS \\
\hline Recycling applications and infrastructure & 3.3810 & 0.73259 \\
\hline Qualification \& Sensitivity & 3.2456 & 0.79314 \\
\hline Responsibility & 3.6608 & 0.63462 \\
\hline Green advertising practices & 4.1345 & 0.58030 \\
\hline Financial factors & 2.3509 & 0.89625 \\
\hline Green marketing perception & 3.4756 & 0.49746 \\
\hline Pressure and external origin & 3.4605 & 0.69724 \\
\hline Standards and environmental origin & 3.9649 & 0.52491 \\
\hline Responsibility - sensitivity origin & 3.6082 & 0.64280 \\
\hline Reasons for implementation of green marketing & 3.6842 & 0.46612 \\
\hline
\end{tabular}

The highest turnout of sub dimension becomes green advertising practices by participants where as financial factors of green marketing becomes the most negative point of view when the descriptive statistics for the scales and subdimensions are examined. 


\subsection{Comparisons}

\subsubsection{Comparisons on Educational Attainment}

Table 10. Test of Hypothesis $\mathrm{H}_{1}$ and $\mathrm{H}_{2}$

\begin{tabular}{|c|c|c|c|c|c|c|}
\hline & & $\mathrm{N}$ & Average & SS & $\mathrm{F}$ & $p$ \\
\hline \multirow{5}{*}{$\begin{array}{l}\text { Recycling applications and } \\
\text { infrastructure }\end{array}$} & $\begin{array}{l}\text { Primary } \\
\text { School }\end{array}$ & 1 & 4.0000 & . & \multirow{5}{*}{1.069} & \multirow{5}{*}{0.370} \\
\hline & High School & 15 & 3.1524 & 0.77960 & & \\
\hline & University & 31 & 3.5023 & 0.70070 & & \\
\hline & Postgraduate & 10 & 3.2857 & 0.75292 & & \\
\hline & Total & 57 & 3.3810 & 0.73259 & & \\
\hline \multirow{5}{*}{ Qualification \& Sensitivity } & $\begin{array}{l}\text { Primary } \\
\text { School }\end{array}$ & 1 & 4.3333 & . & \multirow{5}{*}{1.755} & \multirow{5}{*}{0.167} \\
\hline & H.school & 15 & 3.2444 & 0.87710 & & \\
\hline & University & 31 & 3.3441 & 0.65819 & & \\
\hline & Postgraduate & 10 & 2.8333 & 0.95904 & & \\
\hline & Total & 57 & 3.2456 & 0.79314 & & \\
\hline \multirow{5}{*}{ Responsibility } & $\begin{array}{l}\text { Primary } \\
\text { School }\end{array}$ & 1 & 4.0000 & . & \multirow{5}{*}{1.860} & \multirow{5}{*}{0.148} \\
\hline & H.school & 15 & 3.9111 & 0.62319 & & \\
\hline & University & 31 & 3.6344 & 0.62867 & & \\
\hline & Postgraduate & 10 & 3.3333 & 0.58794 & & \\
\hline & Total & 57 & 3.6608 & 0.63462 & & \\
\hline \multirow{5}{*}{ Green Advertising Practices } & $\begin{array}{l}\text { Primary } \\
\text { School }\end{array}$ & 1 & 5.0000 & . & \multirow{5}{*}{2,933} & \multirow{5}{*}{0,52} \\
\hline & H.School & 15 & 3.8222 & 0.61550 & & \\
\hline & University & 31 & 4.2581 & 0.51431 & & \\
\hline & Postgraduate & 10 & 4.1333 & 0.57090 & & \\
\hline & Total & 57 & 4.1345 & 0.58030 & & \\
\hline \multirow{5}{*}{ Financial Factors } & $\begin{array}{l}\text { Primary } \\
\text { School }\end{array}$ & 1 & 2.0000 & 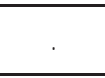 & \multirow{5}{*}{.777} & \multirow{5}{*}{.512} \\
\hline & H.School & 15 & 2.5333 & 1.06010 & & \\
\hline & University & 31 & 2.3871 & 0.84370 & & \\
\hline & Postgraduate & 10 & 2.0000 & 0.81650 & & \\
\hline & Total & 57 & 2.3509 & 0.89625 & & \\
\hline \multirow{5}{*}{ Green Marketing Perception } & Pri. School & 1 & 4.1111 & & \multirow{5}{*}{1,388} & \multirow{5}{*}{0,257} \\
\hline & H.school & 15 & 3.3741 & 0.56284 & & \\
\hline & University & 31 & 3.5556 & 0.45610 & & \\
\hline & Postgraduate & 10 & 3.3167 & 0.49139 & & \\
\hline & Total & 57 & 3.4756 & 0.49746 & & \\
\hline \multirow{5}{*}{ Pressure and External Origin } & $\begin{array}{l}\text { Primary } \\
\text { School }\end{array}$ & 1 & 4.7500 & - & \multirow{5}{*}{2.781} & \multirow{5}{*}{0.050} \\
\hline & H.School & 15 & 3.7500 & 0.48181 & & \\
\hline & University & 31 & 3.3145 & 0.78784 & & \\
\hline & Postgraduate & 10 & 3.3500 & 0.42817 & & \\
\hline & Total & 57 & 3.4605 & 0.69724 & & \\
\hline \multirow{5}{*}{ Standards and environmental origin } & $\begin{array}{l}\text { Primary } \\
\text { School }\end{array}$ & 1 & 4.7500 & & \multirow{5}{*}{1.663} & \multirow{5}{*}{0.186} \\
\hline & H.School & 15 & 3.7667 & 0.50415 & & \\
\hline & University & 31 & 4.0242 & 0.44420 & & \\
\hline & Postgraduate & 10 & 4.0000 & 0.71686 & & \\
\hline & Total & 57 & 3.9649 & 0.52491 & & \\
\hline Responsibility - sensitivity origin & $\begin{array}{l}\text { Primary } \\
\text { School }\end{array}$ & 1 & 4.3333 & 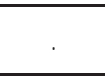 & 0,681 & 0,568 \\
\hline
\end{tabular}




\begin{tabular}{|c|c|c|c|c|c|c|}
\hline & H.School & 15 & 3.6444 & 0.58373 & & \\
\hline & University & 31 & 3.6237 & 0.69251 & & \\
\hline & Postgraduate & 10 & 3.4333 & 0.58899 & & \\
\hline & Total & 57 & 3.6082 & 0.64280 & & \\
\hline \multirow{5}{*}{$\begin{array}{l}\text { Reasons for implementation of green } \\
\text { marketing }\end{array}$} & $\begin{array}{l}\text { Primary } \\
\text { School }\end{array}$ & 1 & 4.6364 & . & \multirow{5}{*}{1.606} & \multirow{5}{*}{0.199} \\
\hline & H.School & 15 & 3.7273 & 0.39626 & & \\
\hline & University & 31 & 3.6569 & 0.49777 & & \\
\hline & Postgraduate & 10 & 3.6091 & 0.41116 & & \\
\hline & Total & 57 & 3.6842 & 0.46612 & & \\
\hline
\end{tabular}

As a result of the one-way analysis of variance among the different education level managers, it is understood that, there was not a significant difference with the perception of green marketing, views on green marketing practice and its subdimensions. $(p>0.05)$

\subsubsection{Comparisons Related to Duration Of Activity}

Table 11. Test of Hypothesis $\mathrm{H}_{3}$ and $\mathrm{H}_{4}$

\begin{tabular}{|c|c|c|}
\hline & & Faaliyet Süresi \\
\hline \multirow{3}{*}{ Recycling applications and infrastructure } & Pearson Correlation & 0.104 \\
\hline & $\mathrm{P}$ & 0.440 \\
\hline & $\mathrm{N}$ & 57 \\
\hline \multirow{3}{*}{ Qualification \& Sensitivity } & Pearson Correlation & 0.074 \\
\hline & $\mathrm{P}$ & 0.585 \\
\hline & $\mathrm{N}$ & 57 \\
\hline \multirow{3}{*}{ Responsibility } & Pearson Correlation & 0.028 \\
\hline & $\mathrm{P}$ & 0.836 \\
\hline & $\mathrm{N}$ & 57 \\
\hline \multirow{3}{*}{ Green Advertising Practices } & Pearson Correlation & -0.259 \\
\hline & $\mathrm{P}$ & 0.052 \\
\hline & $\mathrm{N}$ & 57 \\
\hline \multirow{3}{*}{ Financial Factors } & Pearson Correlation & 0.062 \\
\hline & $\mathrm{P}$ & 0.649 \\
\hline & $\mathrm{N}$ & 57 \\
\hline \multirow{3}{*}{ Green Marketing Perception } & Pearson Correlation & 0.050 \\
\hline & $\mathrm{P}$ & 0.713 \\
\hline & $\mathrm{N}$ & 57 \\
\hline \multirow{3}{*}{ Pressure and External Origin } & Pearson Correlation & -0.088 \\
\hline & $\mathrm{P}$ & 0.514 \\
\hline & $\mathrm{N}$ & 57 \\
\hline \multirow{3}{*}{ Standards and environmental origin } & Pearson Correlation & -0.183 \\
\hline & $\mathrm{P}$ & 0.173 \\
\hline & $\mathrm{N}$ & 57 \\
\hline \multirow{3}{*}{ Responsibility - sensitivity origin } & Pearson Correlation & 0.074 \\
\hline & $\mathrm{P}$ & 0.582 \\
\hline & $\mathrm{N}$ & 57 \\
\hline \multirow{3}{*}{ Reasons for implementation of green marketing } & Pearson Correlation & -0.095 \\
\hline & $\mathrm{P}$ & 0.482 \\
\hline & $\mathrm{N}$ & 57 \\
\hline
\end{tabular}

As a result of the correlation analysis, the following facts were obtained:

- There is no meaningful relationship between the total score of responses related to duration of activity of the organization and "recycling applications and infrastructure". ( $p>0.05, a=0.05)$ 
- There is no meaningful relationship between the total score of responses related to duration of activity of the organization and "Qualification - Sensitivity"sub dimension. ( $p>0.05, a=0.05)$

- There is no meaningful relationship between the total score of responses related to duration of activity of the organization and "Responsibility". ( $p>0.05, a=0.05$ )

- There is no meaningful relationship between the total score of responses related to duration of activity of the organization and "Green Advertising Practices"sub dimension. ( $p>0.05, a=0.05)$

- There is no meaningful relationship between the total score of responses related to duration of activity of the organization and "Financial Factors"sub dimension. ( $p>0.05, a=0.05)$

- There is no meaningful relationship between the total score of responses related to duration of activity of the organization and" Green Marketing Perception "sub dimension. ( $p>0.05, a=0.05)$

- There is no meaningful relationship between the total score of responses related to duration of activity of the organization and "Pressure and External Origin" sub dimension. ( $p>0.05, a=0.05)$

- There is no meaningful relationship between the total score of responses related to duration of activity of the organization and "Standards and Environmental Origin " sub dimension. ( $p>0.05, a=0.05)$

- There is no meaningful relationship between the total score of responses related to duration of activity of the organization and" Responsibility - sensitivity origin" sub dimension. ( $p>0.05, a=0.05)$

- There is no meaningful relationship between the total score of responses related to duration of activity of the organization and "Reasons for implementation of green marketing"scale. ( $p>0.05, a=0.05)$

\subsubsection{Comparisons Related to Number Of Staff}

Table 12. Test of Hypothesis $\mathrm{H}_{5}$ and $\mathrm{H}_{6}$

\begin{tabular}{|c|c|c|c|c|c|c|}
\hline & & $\mathrm{N}$ & Ortalama & SS & $F$ & $p$ \\
\hline \multirow{4}{*}{ Recycling applications and infrastructure } & $1-49$ & 43 & 3.3621 & 0.77079 & \multirow{4}{*}{0.117} & \multirow{4}{*}{0.890} \\
\hline & $50-199$ & 11 & 3.4026 & 0.69346 & & \\
\hline & 200 and + & 3 & 3.5714 & 0.28571 & & \\
\hline & Total & 57 & 3.3810 & 0.73259 & & \\
\hline \multirow{4}{*}{ Qualification \& Sensitivity } & $1-49$ & 43 & 3.3023 & 0.66989 & \multirow{4}{*}{4.147} & \multirow{4}{*}{0.021} \\
\hline & $50-199$ & 11 & 2.7879 & 1.07778 & & \\
\hline & 200 and+ & 3 & 4.1111 & 0.19245 & & \\
\hline & Total & 57 & 3.2456 & 0.79314 & & \\
\hline \multirow{4}{*}{ Responsibility } & $1-49$ & 43 & 3.6899 & 0.63577 & \multirow{4}{*}{0.254} & \multirow{4}{*}{0.777} \\
\hline & $50-199$ & 11 & 3.6061 & 0.64667 & & \\
\hline & 200 and + & 3 & 3.4444 & 0.76980 & & \\
\hline & Total & 57 & 3.6608 & 0.63462 & & \\
\hline \multirow{4}{*}{ Green Advertising Practices } & $1-49$ & 43 & 4.1550 & 0.58350 & \multirow{4}{*}{0.291} & \multirow{4}{*}{0.749} \\
\hline & $50-199$ & 11 & 4.1212 & 0.65443 & & \\
\hline & 200 and+ & 3 & 3.8889 & 0.19245 & & \\
\hline & Total & 57 & 4.1345 & 0.58030 & & \\
\hline \multirow{4}{*}{ Financial Factors } & $1-49$ & 43 & 2.2791 & 0.93416 & \multirow{4}{*}{0.998} & \multirow{4}{*}{0.375} \\
\hline & $50-199$ & 11 & 2.4545 & 0.68755 & & \\
\hline & 200 and+ & 3 & 3.0000 & 1.00000 & & \\
\hline & Total & 57 & 2.3509 & 0.89625 & & \\
\hline \multirow{4}{*}{ Green Marketing Perception } & $1-49$ & 43 & 3.4806 & 0.51261 & \multirow{4}{*}{0.274} & \multirow{4}{*}{0.762} \\
\hline & $50-199$ & 11 & 3.4091 & 0.51417 & & \\
\hline & 200 and + & 3 & 3.6481 & 0.13981 & & \\
\hline & Total & 57 & 3.4756 & 0.49746 & & \\
\hline \multirow{4}{*}{ Pressure and External Origin } & $1-49$ & 43 & 3.5116 & 0.73183 & \multirow{4}{*}{1.265} & \multirow{4}{*}{0.291} \\
\hline & $50-199$ & 11 & 3.1818 & 0.56003 & & \\
\hline & 200 and+ & 3 & 3.7500 & 0.43301 & & \\
\hline & Total & 57 & 3.4605 & 0.69724 & & \\
\hline \multirow{2}{*}{ Standards and environmental origin } & $1-49$ & 43 & 4.0698 & 0.43069 & \multirow{2}{*}{3.853} & \multirow{2}{*}{0.027} \\
\hline & $50-199$ & 11 & 3.6364 & 0.71906 & & \\
\hline
\end{tabular}




\begin{tabular}{|c|c|c|c|c|c|c|}
\hline & 200 and + & 3 & 3.6667 & 0.52042 & & \\
\hline & Total & 57 & 3.9649 & 0.52491 & & \\
\hline \multirow{4}{*}{ Responsibility - sensitivity origin } & $1-49$ & 43 & 3.6434 & 0.63160 & \multirow{4}{*}{0.383} & \multirow{4}{*}{0.684} \\
\hline & $50-199$ & 11 & 3.4545 & 0.76409 & & \\
\hline & 200 and + & 3 & 3.6667 & 0.33333 & & \\
\hline & Total & 57 & 3.6082 & 0.64280 & & \\
\hline \multirow{4}{*}{$\begin{array}{l}\text { Reasons for implementation of green } \\
\text { marketing }\end{array}$} & $1-49$ & 43 & 3.7505 & 0.46231 & \multirow{4}{*}{2.284} & \multirow{4}{*}{0.112} \\
\hline & $50-199$ & 11 & 3.4215 & 0.44401 & & \\
\hline & 200 and+ & 3 & 3.6970 & 0.36740 & & \\
\hline & Total & 57 & 3.6842 & 0.46612 & & \\
\hline
\end{tabular}

As a result of a one-way analysis of variance with the managers of organizations employing workers with different numbers, it is seen that there is not a meaningful difference among their opinions on green marketing perception and reasons for green marketing implementations. However, there is a meaningful difference among their opinions on qualification and sensitivity which is a sub dimension of green marketing perception and standards and environmental origin practises.

In order to determine in which groups there is a difference pairwise comparisons are done with Tukey test and the results are given below:

Table 13. Results of Tukey Test

\begin{tabular}{|c|c|c|c|c|}
\hline & (I) Personnel & (J) Personnel & $\begin{array}{l}\text { Avg. difference } \\
(\mathrm{I}-\mathrm{J})\end{array}$ & $\mathrm{p}$ \\
\hline \multirow{6}{*}{ Qualification \& Sensitivity } & \multirow{2}{*}{$1-49$} & 50-199 & 0.51445 & 0.116 \\
\hline & & 200 and + & -0.80879 & 0.179 \\
\hline & \multirow{2}{*}{ 50-199 } & $1-49$ & -0.51445 & 0.116 \\
\hline & & 200 and + & $-1.32323^{*}$ & 0.025 \\
\hline & \multirow{2}{*}{200 and + } & $1-49$ & 0.80879 & 0.179 \\
\hline & & 50-199 & $1.32323^{*}$ & 0.025 \\
\hline \multirow{6}{*}{ Standards and environmental origin } & \multirow{2}{*}{$1-49$} & $50-199$ & $0.43340^{*}$ & 0.035 \\
\hline & & 200 and + & 0.40310 & 0.374 \\
\hline & \multirow{2}{*}{$50-199$} & $1-49$ & $-0.43340^{*}$ & 0.035 \\
\hline & & 200 and + & -0.03030 & 0.995 \\
\hline & \multirow{2}{*}{200 and +} & $1-49$ & -0.40310 & 0.374 \\
\hline & & $50-199$ & 0.03030 & 0.995 \\
\hline
\end{tabular}

As shown on Tukey Test Table, when the managers working in a business employing a staff of or over 200 are compared to managers working in a business employing a staff of $50-199$ it is seen that opinions of managers in the first group on qualification and sensitivity that is the sub dimension of green marketing perception are significantly higher (more positive) than the managers' of the second group. In addition, managers of businesses with the number of employees between 1-49 think in a more positive way on the standards and environmental origin green marketing implementations than the managers of businesses working with 50 - 199 employees.

\section{Results and Discussion}

Green marketing is perceived as an advertisement of environmentally sensitive products by a lot of people. However, green marketing, is a much more comprehensive concept including all stages from the production of all goods and services to after-sales promotion. It is only possible for businesses to survive in case they produce environmentally friendly products. When the participants of this green marketing implementation study are analyzed in terms of demographic characteristics, the following results are obtained:

- The majority of participants involved in the study, are marketing managers with percent of $26.3 \%$. Managers and company owners are with a number of $19.3 \%$ in the second place in this category..

- The majority of the participants (54.4\%.)have university-level education. 
- When the distribution of the number of staff working in the firm is analyzed it is seen that; $1-49$ employees work in $75.4 \%$ of the businesses while 50-199 work in\%19,3 and more than 200 people are employed in 5.3\% of the businesses.

- When the businesses are examined in terms of the duration of activity, it is seen they have been active in an average of 15 years. The minimum duration of activity is 5 and the maximum is 42 years.

- When the views of participants on green marketing and the reasons for implementation of green marketing are analyzed, the following results are obtained:

- When the replies related to green marketing perception are examined, it is clearly seen that the judgement' the aim of the green ads should be to provide clear, realistic information to consumers about the environmental effects of the product' becomes the most accepted one with an average of 4.36 among the judgements of participants. On the other hand, the judgement "Environmental impact isn 't taken into consideration during production in our organization" becomes the least accepted one with an average of 2.21.

- When the replies related to green marketing implementation reasons are examined, it is clearly seen that the judgements' Social responsibility of organizations and" Increasing concern of safety and health depending on the environment"become the most accepted one with an average of 4.12 among the judgements of participants. On the other hand, the judgement "Management has become environmentally aware" becomes the least accepted one with an average of 3.12

- When the descriptive statics related to scales and sub dimensions, it is understood that the most accepted sub dimension is green advertising practices whereas financial costs related to green marketing come out as the most negative judgement.

Finally when the comparisons related to scales are analyzed the following results are obtained; among the different education level managers, it is understood that, there is not a significant difference with the perception of green marketing, views on green marketing practice and its sub-dimensions. Among the managers of organizations employing workers with different numbers, it is seen that there is not a meaningful difference among their opinions on green marketing perception and reasons for green marketing implementations. However, there is a meaningful difference among their opinions on qualification and sensitivity which is a sub dimension of green marketing perception and standards and environmental origin practises which are sub dimensions of reasons for green marketing imlementations. When the managers working in a business employing a staff of or over 200 are compared to managers working in a business employing a staff of $50-199$ it is seen that opinions of managers in the first group on qualification and sensitivity that is the sub dimension of green marketing perception are significantly higher (more positive ) than the managers' of the second group. In addition, managers of businesses with the number of employees between 1-49 think in a more positive way on the standards and environmental origin green marketing implementations than the managers of businesses working with $50-199$ employees. There is not a meaningful relationship between the duration of activity of the businesses and the views on green marketing perception and reasons for implementation of green marketing.

\section{References}

Ar, A. Aybeniz (2011). Tekstil Sektöründen Örneklerle Yeşil Pazarlama. İstanbul: Beta Yayıncılık.

Ekinci, B. Tolga (2007). Yeşil Pazarlama Uygulamalarında Yaşanan Sorunlar ve Örnek Bir Uygulama. Yayınlanmamış Yüksek Lisans Tezi, Marmara Üniversitesi, Sosyal Bilimler Enstitüsü, İstanbul.

Evirgen, M. Muzaffer (1997). Çevresel Etik, Ege vizyon Ege Sanayicileri ve İşadamları Derneği, 4, 15, 34.

Grove, Stephen J. ,Raymond P.Fisk, Gregory M. Pickett, Norman Kangun (1996).Going Green In The Service Sector Social Responsibility Issues, Implications And Implementation, Europen Journal of Marketing, Vol:30,N:5,pp:56-6.

Jari, Karna, Eric Hansen and Heikki Juslin (2003). Social Responsibility in Environmental Marketing Planning. European Journal Of Marketing, Vol: 37, No: 5/6, 849.

Kacur, L. Lebleci (2008). Yeşil Pazarlama ve Kayseri'deki İşletmeler Üzerine Bir Uygulama. Yayınlanmamış Doktora Tezi, Erciyes Üniversitesi, Sosyal Bilimler Enstitüsü, Kayseri.

Keleş, Ceyda (2007). Yeşil Pazarlama Tüketicilerin Yeşil Ürünleri Tüketme Davranışları ve Yeşil Ürünlerin Tüketiminde Kültürün Etkisi İle İlgili Bir Uygulama. Yayınlanmamış Yüksek Lisans Tezi, Çukurova Üniversitesi, Sosyal Bilimler Enstitüsü, Adana.

Ken, Peattie (2001) "Towards Sustainability: The Third Age Of Green Marketing", The Marketing Review,

Marangoz, Mehmet (2003). Yeşil Pazarlama ve İsletmelerin Yeşil Pazarlama Anlayış ve Uygulamalarının Değerlendirilmesine Yönelik Bir Araştırma. Yayınlanmamış Doktora Tezi, Dokuz Eylül Üniversitesi Sosyal Bilimler Enstitüsü, İzmir.

Murthy, P.S.R. (2010) Strategic Green Marketing-For Survival, available at SSRN:http://ssrn.com/abstract=1650560 or doi:10.2139/ssrn.1650560. No: 2, 2001, s. 129.; Özata, ", http://zeynepozata.wordpress.com/2006/05/10/yesil-pazarlama/, Erişim Tarihi: 12/06/2006. 
Ottman, Jacquelyn (1993). Green Marketing: Challenges and Opportunities for The New Marketing Age, Lincolnwood, Illinois: NTC Business Books.

Polonsky, M. (1994). An Introduction to Green Marketing, The Internet htpp/www.drseuss.lib.uidaho.edu:70/docs/egj02/polon01.html, Erişim Tarihi, 13.12.2011.

Singh, Preeti (2010). Green Marketing: Opportunity for Innovation and Sustainable Development. Jhunjhunwala Business School, Faizabad.

Stanton, A., and Futrell, M.J. (1993). Marketing And The Ecological Crisis, New York: Harper\&Row.

Torlak, Ömer (2009). "Modern Dünyada Yeşil Pazarlama Ne Ifade Ediyor?".Çerçeve Dergisi, Ocak, 108-112.

Turgul, Çağla (2009). Geleneksel Pazarlama ile Yeşil Pazarlama Stratejilerinin Karşılaştırmalı Analizi. Yayınlanmamış Yüksek Lisans Tezi. Marmara Üniversitesi, Güzel Sanatlar Enstitüsü, İstanbul.

Türk, Mevlüt ve Gök, Ayda (2010). Yeşil Pazarlama Anlayışı Açısından Işletmelerin Sosyal Sorumluluğu. Elektronik Sosyal Bilimler Dergisi, 9, 32, 199-220.

Uydaci, Mert (2011). Yeşil Pazarlama. İstanbul: Türkmen Kitabevi.

Yilmaz, Emel (2003). Sanayi İşletmeleri Açısından Çevre ve Yeşil Pazarlama (Green Marketing). Yayınlanmamış Yüksek Lisan Tezi, Celal Bayar Üniversitesi, Sosyal Bilimler Enstitüsü, Manisa. 